\title{
Morphometrical development of tambaqui (Colossoma macropomum, Cuvier, 1818) under different photoperiods
}

\author{
Pedro Pierro Mendonça ${ }^{1^{*}}$, Manuel Vazquez Vidal Junior ${ }^{2}$, Marcelo Fanttini Polese ${ }^{3}$, Monique \\ Virães Barbosa dos Santos ${ }^{4}$, Fabrício Pereira Rezende ${ }^{5}$, Dalcio Ricardo de Andrade ${ }^{2}$ \\ ${ }^{1}$ Doutorando em Ciência Animal - LZNA/CCTA/UENF. \\ 2 LZNA/ CCTA/UENF, Campos dos Goytacazes, RJ, Brasil. \\ ${ }^{3}$ Mestrando em Ciência Animal - LZNA/CCTA/UENF. \\ ${ }^{4}$ Mestranda em Produção Animal - LZNA/CCTA/UENF. \\ ${ }^{5}$ Doutorando em Zootecnia/EMBRAPA Pesca e Aquicultura - Palmas, TO.
}

ABSTRACT - The experiment was performed with 160 tambaqui (Colossoma macropomum) with average weight $11.01 \pm 2.08 \mathrm{~g}$ and total length $7.8 \pm 0.18 \mathrm{~cm}$. Fishes were kept in sixteen aquariums with $56 \mathrm{~L}$ of water at $29.1 \pm 0.4{ }^{\circ} \mathrm{C}$ of temperature, initial stocking density $1.97 \mathrm{~g} / \mathrm{L}$ and constant aeration. The objective of this study was to assess the influence of photoperiod on fish performance. Treatments consisted of four photoperiods: T1 $=6$ hours; T2 $=12$ hours; T3 = 18 hours and T4 $=24$ hours, with four replicates each. Fishes were fed twice a day with commercial extruded feed ( $28 \%$ of crude protein). The experiment was developed in closed circulation system, with volume of water renewal for each experimental unit equivalent to 40 times daily. Fish biometry was performed at the beginning of the experiment and at every 16 days, in order to follow the effects of treatments on juvenile development. Final weight, total length, standard length, height, feed intake, weight gain, feed conversion, survival, specific growth rate, protein efficiency rate and protein retention efficiency were assessed. Statistical analysis of variables was performed with application of the software SAEG version 9.1, for analysis of variance, regression analysis and Pearson correlation. Positive influence of photoperiod was observed for the studied variables in this study. The studied variables enhanced as the photoperiod increased, mainly between 15 and 22 hours. The photoperiod has significant influence upon growth traits of tambaqui (Colossoma macropomum).

Key Words: bioclimatology, growth, native fish

\section{Introduction}

Fish farming is one of the activities that have positive economic growth every year, due to the increasing world demand for fish. Therefore, deeper knowledge of species with productive potential, such as tilapia, carp and native species such as tambaqui, arapaima, pacu, pintado among others, is needed.

Most of the native species with commercial potential in Brazil and around the world are from the Amazon, not only for their size, growth rate or taste, but mainly because these species evolved withstanding low levels of dissolved oxygen in water. Other factors that contributed to diffusion, specially of tambaqui (Colossoma macropomum), and other species such as characin fishes like pacu and pirapitinga, were the development and publication of a protocol for juvenile production allied to the good fecundity of these species (Silva et al., 1981; Woynarovich, 1986).

Tambaqui (Colossoma macropomum, Cuvier, 1818) is a native species from the Amazon, and has been an issue of interest of researchers and farmers due to its adaptation to intensive production, fast growth, acceptance into the industrial feed and high value of its meat.

Tambaqui was taken to Panamá and Taiwan in the eighties and lately, to Cuba, Dominican Republic, United States, Honduras, Jamaica, Philippines, Guatemala, Hungary, Costa Rica, Porto Rico and China, where they are grown or live in free populations in the nature (Liao et al. 2001).

The state of Amazonas is located between the Capricornia and Cancer Tropics, considered as a tropical region, with longer periods of sunlight and high temperatures. Tambaqui is a fish of daylight feeding habits, therefore longer periods of light optimize its metabolism and stimulates feed intake, which explains the research studies concerning the influence of light on the development of this fish. Some authors, working in this line, observed satisfactory results, like Puvanendran \& Brown (2002), who verified that Atlantic cod larvae (Gadus morhua) presented better growth and survival in high light intensity and in photoperiods of 24L:0D. 
Photoperiod affects physiology of growth and reproduction of fish. Also, the lack of information about the effect of environmental factors for Brazilian fish can be noticed. Thus, the effect of photoperiod on the development of fingerlings of tambaqui is the scope of this study.

\section{Material and Methods}

The experiment was performed in the Agriculture Sector of Universidade Estadual do Norte Fluminense (UENF/RJ), Campos dos Goytacazes, Rio de Janeiro, Brazil, during the period between May 4 and June 21 of 2006, comprising 48 days.

One hundred and sixty juveniles of tambaqui Colossoma macropomum, from the fish farming station Projeto Piabanha, located in Itaocara, Rio de Janeiro State, Brazil were used. The age of the specimens was approximately 60 days; fishes were distributed in 16 aquariums with approximate measures of $30 \times 60 \times 50 \mathrm{~cm}$ (width, length, height), using the volume of 56 liters of water for each aquarium, which received 10 juvenile tambaqui, resembling an experimental unit.

Experimental units were distributed in a randomized blocks design, with two blocks that contained two replicates for each treatment, and composed according to the difference of light intensity that reached the replicates and four treatments. Treatments differed in the simulations of photoperiods (hours of light) $\mathrm{T} 1=6 \mathrm{~h}, \mathrm{~T} 2=12 \mathrm{~h}, \mathrm{~T} 3=18 \mathrm{~h}$ and $\mathrm{T} 4=24 \mathrm{~h}$ of artificial light.

The light intensity used in the experiment was quantified by a photometer, measured in ìmol $/ \mathrm{m}$.s. Hours of light supplied throughout the experiment was controlled by automatic timers that turned the lights on and off during the programmed period.

Treatments were isolated with black PVC to avoid light incidence from other sources during the dark period of each treatment, assuring that the supply of light would only happen during the programmed periods for each treatment.

The following water quality parameters were measured: dissolved oxygen, $\mathrm{pH}$, temperature and electrical conductivity. The measures were obtained always after feeding (at 8:20 a.m. and 1:20 p.m). The levels of oxygen were kept with aerators; the oxygen was measured by oxygen sensor, $\mathrm{pH}$ was measured by a $\mathrm{pH}-$ meter, temperature by a digital thermometer, and electrical conductivity by an electrical conductivity analyzer.

Experimental aquariums were kept under a continuous closed recirculating system containing a wet/dry filter with a pre box for decantation and a return box with thermostats to maintain the water temperature.
Water circulation rate was 40 times the total volume per day. Water flow was constant, aiming to keep the oxygen saturation high and remove feces, avoiding the plankton formation.

Feeding management was done with commercial feed containing $28 \%$ of crude protein (CP) and 3,100 kcal of digestible energy (DE) $/ \mathrm{kg}$. Animals were fed twice a day with 5 hours of interval between the first and the second meal, at 8:20 a.m. and 1:20 p.m. After 15 minutes, the leftovers were cleaned from the aquariums. Feeding was supplied until every aquarium presented some amount of leftovers.

The initial stocking density was $1.97 \mathrm{~g} / \mathrm{L}$ in each aquarium and juvenile fish went through a process of adaptation to the experimental routin, which lasted 12 days. At the 32nd experimental day, 50 animals from each replicate were slaughtered.

Biometry was made in the beginning of the experiment and at every 16 days during the experimental period aiming to assess total body length in $\mathrm{cm}$, standard body length in $\mathrm{cm}$, body height in $\mathrm{cm}$ and body weight in $\mathrm{g}$. Feed intake was measured in grams by the difference between feed offered and leftovers.

Biometry, along with feeding management allowed the calculation of some parameters such as: body weight gain $(\mathrm{g})$, feed conversion ( $\mathrm{g})$, daily weight gain rate $(\%)$, specific growth rate (\%) and protein efficiency rate (\%).

Statistical analysis of the experiment was done with statistical software SAEG (Sistema para Análises Estatísticas, version 9.1), of Universidade Federal de Viçosa. Analysis of variance, Simple and Multiple Linear Regressions, Linear Response Plateau and Pearson Correlations were made with data obtained from measurements performed during the experimental period.

\section{Results and Discussion}

According to Araujo-Lima \& Gomes (2005), tambaqui presents normal growth at oxygen levels above $3 \mathrm{mg} / \mathrm{L}$. Therefore, the values obtained in this experiment $(5.75 \mathrm{mg} / \mathrm{L})$ perfectly supply the tambaqui requirement. Similarly, average values of $\mathrm{pH}$ were kept between 4.0 and 6.5 , within the recommended standards by Aride et al. (2004). The temperature of the experimental aquariums was adequate for tropical climate species, presenting average values of $29.45^{\circ} \mathrm{C}$ in the morning and $28.80^{\circ} \mathrm{C}$ in the afternoon (Table 1).

The Intensity of the light used in the experiment did not differ between treatments, $(\mathrm{T} 1=0.1067 ; \mathrm{T} 2=0.1050 ; \mathrm{T} 3=$ $\left.0.1050 ; \mathrm{T} 4=0.0967 \mu \mathrm{mol} / \mathrm{m}^{2} . \mathrm{s}\right)$, but there was a difference in blocks concerning the amount of $\mu \mathrm{mol} / \mathrm{m}^{2}$.s that reached the replicates, $\left(\right.$ block $1=0.0819 \mu \mathrm{mol} / \mathrm{m}^{2} . \mathrm{s}$ and block $2=$ 
$0.1416 \mu \mathrm{mol} / \mathrm{m}^{2}$.s.) Block 1 was composed of replicates 1 and 4 and block 2 , of replicates 2 and 3 .

The third biometry (32nd experimental day) presented a high average weight, mainly in treatments 3 and 4 , generating a high density situation inside the experimental aquariums. In order to reduce density inside those aquariums, some fishes that composed each replicate of every treatment were slaughtered.

Results obtained from biometry in this experiment were higher for the following variables: total length, standard length and weight in the treatments of longer photoperiods (Table 2), determining a better development of juvenile tambaqui in those photoperiods.

The Linear Response Plateau (LRP) analysis for the variables (Table 2) showed that better responses were obtained with photoperiods above 15 hours.

Several authors have reported positive effects of longer photoperiods in fish development. Longer photoperiods (18HL:6HD and 24HL:0HD) provided better results of Latris lineatus larvae development than shorter photoperiod (12HL:12HD) (Trotter et al., 2003).

Results similar to the ones observed in this study were reported for different species and development phases. Flounder larvae (Paralichthys lethostigma)
(Moustakas et al., 2004) and Atlantic cod larvae (Gadus morhua), described by Puvanendran \& Brown (2002) and haddock juvenile (Melanogrammus aeglefins), reported by Trippel \& Neil (2003), presented better development when exposed to longer photoperiods and lighting of high intensity.

Some authors did not observe significant differences or positive responses with the increase in photoperiod in the initial stages of development of some species used in fish farming. Reynalte-Tataje et al. (2002) worked with piracanjuba larvae (Brycon orbignyanus) and did not observe significant differences for length or weight $(\mathrm{P}<0.05)$ in photoperiods of 0 hours of light (HL):24 hours of dark (HD), 10HL:14HD, 14HL:10HD and 24HL:0HD, during 10 days of experimental period. The same authors observed more heterogeneity as photoperiod decreased, and the treatment 0HL:24HD resulted in the maximum and minimum values for weight 12 to $94 \mathrm{mg}$ for 11 and $22 \mathrm{~mm}$ of length, respectively. The best results for weight gain, feed intake and feed conversion were observed as the photoperiod increased (Table 3 ).

Salaro et al. (2006), worked with trairao fingerlings (Hoplias lacerdae) subjected to different photoperiods and did not observe significant differences in weight gain, feed conversion, survival rate or cannibalism.

Table 1 - Mean values of water quality variables measured during the experimental period

\begin{tabular}{|c|c|c|c|c|c|}
\hline \multirow[t]{2}{*}{ Parameters } & & \multicolumn{4}{|c|}{ Treatments (hours of light) } \\
\hline & & 6 & 12 & 18 & 24 \\
\hline Dissolved oxygen $(\mathrm{mg} / \mathrm{L})$ & & 5.90 & 5.80 & 5.60 & 5.70 \\
\hline Electrical conductivity $(\mu \mathrm{S})$ & & 366.00 & 396.00 & 543.00 & 561.00 \\
\hline \multirow[t]{2}{*}{ Temperature $\left({ }^{\circ} \mathrm{C}\right)$} & M & 29.50 & 29.80 & 29.10 & 29.40 \\
\hline & $\mathrm{A}$ & 29,00 & 28.90 & 28.60 & 28.70 \\
\hline
\end{tabular}

M - morning; A - afternoon.

Table 2 - Mean values of total length $(\mathrm{cm})$, standard length $(\mathrm{cm})$, height $(\mathrm{cm})$ and weight $(\mathrm{g})$ of juvenile tambaqui at different photoperiods, in hours, within 48 days of experiment

\begin{tabular}{lcccccccc}
\hline Variables & \multicolumn{7}{c}{ Treatments (hours of light) } \\
\cline { 2 - 7 } & 6 & CV & 12 & CV & 18 & CV & 24 \\
\hline Total length & 12.28 & 0.41 & 12.68 & 1.18 & 12.85 & 0.78 & 13.15 \\
Standard length & 10.73 & 0.56 & 11.13 & 0.45 & 11.13 & 1.35 & 11.48 & 3.92 \\
Height & 5.23 & 2.87 & 5.41 & 1.67 & 5.43 & 0.92 & 5.65 & 5.31 \\
Weight & 41.71 & 2.61 & 44.31 & 2.89 & 45.65 & 0.35 & 51.73 & 14.34 \\
\hline
\end{tabular}

$\overline{\mathrm{CV}}$ - coefficient of variation.

Table 3 - Mean values of weight gain ( $\mathrm{g}$ ), feed intake $(\mathrm{g})$, feed conversion $(\mathrm{g})$ of juvenile tambaqui subjected to different photoperiods (in hours)

\begin{tabular}{lcccccccc}
\hline Variables & \multicolumn{7}{c}{ Treatments (hours of light) } \\
\cline { 2 - 8 } & 6 & CV & 12 & CV & 18 & CV & 24 & CV \\
\hline Weight gain & 29.42 & 1.00 & 32.05 & 7.88 & 33.53 & 2.79 & 39.69 & 20.26 \\
Feed intake & 62.20 & 6.82 & 71.77 & 2.10 & 72.60 & 10.52 & 86.53 & 7.93 \\
Feed conversion & 1.78 & 3.99 & 1.78 & 11.09 & 1.81 & 7.29 & 1.97 & 12.43 \\
\hline
\end{tabular}

$\mathrm{CV}$ - coefficient of variation. 
Luz et al. (2000) also did not find significant difference when evaluating the development of Brazilian catfish cachara larvae (Pseudoplatystoma fasciatum) under 24HL:0HD and 0HL:24HD.

Melo et al. (2001) studied tambaqui fingerlings and found mean value of 1.09 for feed conversion. The high values of feed conversion found in the present experiment may have occurred because some animals were slaughtered on the 32nd day, with the intention to reduce density of replicates and assure animal welfare.

The Linear Response Plateau was calculated to elucidate which would be the longest photoperiod possible for a better response of each variable listed in Table 3, observing the point where variable and treatment meet. Therefore, results were 22:37 hours of light for weight gain and 17:29 hours of light for feed intake. The variable feed conversion presented a statistical behavior that did not allow the calculation of the Linear Response Plateau; thus, the longer possible photoperiod for the best feed conversion could not be statistically demonstrated.

Specific growth rate, protein efficiency ratio, daily weight gain rate and density $(\mathrm{g} / \mathrm{L})$ of fishes within 48 days of experiment were also measured (Table 4).

The mean values of specific growth rate observed in treatments $\mathrm{T} 1, \mathrm{~T} 2, \mathrm{~T} 3, \mathrm{~T} 4$ were respectively $0.37,0.44$, 0.45 and $0.48 \%$ /day, presenting a higher value from treatment T4 (24HL). These values are lower than the ones found by Ituassú et al. (2004), who worked with juvenile tambaqui weighting initially $75.68 \mathrm{~g}$, on average, and found specific growth rate means that ranged from 0.97 to $0.83 \%$ /day.

Fernandes et al. (2004), also estimated specific growth rate values higher than the ones obtained in this study, between 1.64 and $1.80 \%$ /day for pacu fingerlings, just like Ituassú et al. (2005), who observed values of specific growth rate between 1.4 and $2.4 \%$ /day for juvenile pirarucu fed diets with variation of crude protein levels.

Muñoz-Ramirez \& Carneiro (2002) observed even higher values of specific growth rate, between 2.27 and $1.76 \%$ /day, for the initial stage of growth of pacu fed diets with different supplementations of lysine and methionine and low protein value.

The lower values of specific growth rate found in this study may be a result from the stress caused on the $32 \mathrm{nd}$ day, when 5 animals of each experimental unit were slaughtered in order to reduce density of experimental units and perform bromatological analysis of carcass. This management may have caused a disorder in the shoal that unleashed new disputes for leadership and probably impaired the development of these animals.

The feed used in the experiment had $28 \%$ of crude protein $(\mathrm{CP})$, and must not have affected the development of the animals and consequently the variables related to growth, because crude protein level was close to the ideal for juvenile tambaqui recommended by Vidal Junior(1995). That author studied juvenile tambaqui weighting from 30 to $250 \mathrm{~g}$ at $25.8^{\circ} \mathrm{C}$ and observed maximum performance when animals were fed diets containing $25.1 \%$ of CP. Fernandes et al. (2004) also did not observe significant difference between isocaloric feed, but 30 and $26 \%$ of crude protein in feed influenced growth of juvenile pacu.

Means calculated for protein efficiency ratio at the end of 48 days were lower than the ones found by MuñozRamirez \& Carneiro (2002), who observed protein efficiency ratio between 2.34 and 2.73 for juvenile pacu, and Fernandes et al. (2004), who observed protein efficiency ratio around 3.2 to 2.92 for pacu fingerlings fed diets with different levels and sources of protein. Protein efficiency ratio was also calculated by Carneiro et al. (1992), who subjected juvenile pacu to different stocking densities and feed with different protein levels.

The Linear Response Plateau for specific growth rate was 22:38 hours of light and for rate of daily weight gain was 20:35 hours of light. Therefore, treatments of longer photoperiods are closer to those encounter points between photoperiods and variables.

All other variables studied in this experiment presented a linear behavior during the experimental period, except for feed conversion and protein efficiency ratio. This behavior is described by equations obtained from statistical analysis of those variables by the SAEG software.

Table 4 - Mean values of protein efficiency ratio (\%), specific growth rate (\%), daily weight gain rate (\%) and density (g/L) of juvenile tambaqui at different photoperiods

\begin{tabular}{lcccc}
\hline Variables & \multicolumn{3}{c}{ Treatments (hours of light) } \\
\cline { 2 - 5 } & 6 & 12 & 18 & 24 \\
\hline Protein efficiency rate & 1.68 & 1.62 & 1.65 & 1.62 \\
Specific growth rate & 0.37 & 0.44 & 0.45 & 0.48 \\
Daily weight gain rate & 1.10 & 1.16 & 1.20 & 8.92 \\
Density & 8.30 & 8.53 & 9.24 \\
\hline
\end{tabular}


According to the results, the best equations for the following variables were: weight gain, $\mathrm{Y}=37.9950+0.5236 \mathrm{X}$; feed intake, $\mathrm{Y}=54.8175+1.2304 \mathrm{X}$; total length, $\mathrm{Y}=$ $12.0375+0.0466 \mathrm{X}$; and height, $\mathrm{Y}=5.1025+0.0216 \mathrm{X}$. For specific growth rate, the equation that best represented the line was $\mathrm{Y}=0.3779+0.0038 \mathrm{X}$ and for daily weight gain rate, the equation with best adjustment was $\mathrm{Y}=1.0237+0.0124 \mathrm{X}$.

\section{Conclusions}

Photoperiods affect the variables weight gain, feed intake, feed conversion, total and standard length, height, specific growth rate, protein efficiency ratio and daily weight gain rate, and the highest mean values for these variables are obtained with photoperiods above 15 hours of light.

\section{References}

ARAUJO-LIMA, C.A.R.M.; GOMES, L.C. Tambaqui (Colossoma macropomum). In: BALDISSEROTTO, B. GOMES, L.C. (Eds.) Espécies nativas para piscicultura no Brasil. Santa Maria: Editora da UFSM, 2005. 468p.

ARIDE, P.H.R.; ROUBACH, R.; VAL, A.L. Water pH in central Amazon and its importance for tambaqui (Colossoma macropomum) culture. World Aquaculture, v.35, p.24-27, 2004.

CARNEIRO, D.J.; WAGNER, P.M.; DIAS, T.C.R. Efeito da densidade de estocagem e do nível de proteína bruta da dieta, no desempenho de produção do pacu (Piaractus mesopotamicus). In: SIMPÓSIO BRASILEIRO DE AQÜICULTURA, 1992, Peruíbe. Anais... Jaboticabal: CAUNESP, 1992. p.52-61.

FERNANDES, J.B.K.; CARNEIRO, D.J.; SAKOMURA, N.K. Fontes e níveis de proteína bruta em dietas para alevinos de pacu (Piaractus mesopotamicus). Revista Brasileira de Zootecnia, v.29, p.646-653, 2004.

ITUASSÚ, D.R.; PEREIRA-FILHO, M.; ROUBACH, R. et al. Desenvolvimento de tambaqui submetido a períodos de privação alimentar. Pesquisa Agropecuária Brasileira, v.39, n.12, p.1199-1203, 2004.

ITUASSÚ, D.R.; SANTOS G.R.S.; ROUBACH, R. et al. Níveis de proteína bruta para juvenis de pirarucu. Pesquisa Agropecuária Brasileira, v.40, n.3, p.255-259, 2005.
LIAO, I.C.; SU, H.M.; CHANG, E.Y. Techniques in finfish larviculture in TAIWAN. Aquaculture, v.200, p.1-31, 2001.

LUZ, R.K.; SALARO, A.L.; SIROL, R.N. et al. Influência do fotoperíodo no desenvolvimento inicial de surubim cachara (Pseudoplatystoma fasciatum).In: REUNIÃO ANUAL DA SOCIEDADE BRASILEIRA DE ZOOTECNIA, 37., 2000, Viçosa, MG. Anais... Viçosa, MG: Sociedade Brasileira de Zootecnia: [2000]. (CD-ROM)

MELO, L.A.S.; IZEL, A.C.U.; RODRIGUES, F.M. Criação de tambaqui (Colossoma macropomum) em viveiros de argila/ barragens no estado do Amazonas. Manaus: Embrapa Amazônia Ocidental, 2001. 30p.

MOUSTAKAS, C.T.; WATANABE, W.O.; COPELAND, K.A. Combined effects of photoperiod and salinity on growth, survival, and osmoregulatory ability of larval southern flounder (Paralichthys lethostigma). Aquaculture, v.229, p.159-179, 2004.

MUÑOZ-RAMIREZ A.P.; CARNEIRO D.J. Suplementação de lisina e metionina em dietas com baixos níveis protéicos para o crescimento inicial do pacu, Piaractus mesopotamicus (holmberg). Acta Scientiarum, v.24, p.909-916, 2002.

PUVANENDRAN, V.; BROWN, J.A. Foraging, growth and survival of Atlantic cod larvae reared in different light intensities and photoperiods. Aquaculture, v.214, p.131-151, 2002.

REYNALTE-TATAJE, D.; LUZ, S.M.; ZAMBONI-FILHO, E. et al. Influência do fotoperíodo no crescimento e sobrevivência de pós-larvas de piracanjuba Brycon orbignyanusi (Valenciennes, 1849) (Osteichthyes, Characidae). Acta Scientiarum, v.24, p.439-443, 2002 .

SALARO, A.L; LUZ, R.K.; ZUANON, J.A.S. et al. Desenvolvimento de alevinos de trairão (Hoplias lacerdae) na ausência de luz. Acta Scientiarum. Biological Sciences, v.28, p.47-50, 2006

SILVA, A.B.; CARNEIRO-SOBRINHO, A.; MELO, F.R. Desova induzida de tambqui, Colossoma macropomum, Cuvier, 1818, com uso de hipófise de curimatá comum, Prochilodus cearensis Steindachner. In: DNOCS (Ed). $2^{\text {a }}$ Coletânea de trabalhos técnicos. Fortaleza, 1981. p.519-532.

TRIPPEL, E.A.; NEIL, S.R.E. Effects of photoperiod and intensity on growth and activity of juvenile haddock (Melanogrammus aeglefinus) light. Aquaculture, v.217, p.633-645, 2003.

TROTTER, A.J.; BATTAGLENE, S.C; PANKHURST, P.M. et al. Effects of photoeriods and light intensity on initial swin bladder inflation, growth and post inflation viability in cultured stripped trumpeter (Latris lineatus) larvae. Aquaculture, v.224, p.141-158, 2003.

VIDAL JUNIOR, V.V. Níveis de proteína para tambaqui (Colossama macropomum Curvier, 1818) dos 30 aos $250 \mathrm{~g}$ de peso vivo. 1995. 49f. Tese (Mestrado em Zootecnia) Universidade Federal de Viçosa, Viçosa, MG.

WOYNAROVICH, E. Tambaqui e pirapitinga: propagação artificial e criação de alevinos. 3.ed. Brasília: CODEVASF, 1986. 68p. 